\title{
MAKNA EKOKRITIK UNGKAPAN SUNGAI DALAM UJARAN SASTRA KALIMANTAN BARAT
}

\author{
THE ECOCRITICAL MEANING OF THE EXPRESSION OF \\ RIVER IN WEST KALIMANTAN'S LITERARY EXPRESSIONS
}

\author{
Khairul Fuad \\ Balai Bahasa Kalimantan Barat \\ Jln. Jenderal Ahmad Yani/Jalan Balai Bahasa Pontianak, Indonesia \\ khairul.fuad@kemdikbud.go.id,khairulfuad297@gmail.com
}

Diterima tanggal 16 Juni 2020

Disetujui tanggal 8 Juni 2021

\begin{abstract}
A river is an important part of the social and environmental management in West Kalimantan which becomes a marker of the community's existence. Literature is the image of the management since it lives and develops according to its surrounding. The relationship between literature and rivers can be seen in the literary expressions. The image of the river in literature changes over time which is seen in different expression of West Kalimantan's poem. This paper used semiotic-dynamic as an analytical tool to find out the expressions of the river and its changes in literary expression. This analysis tool was used to obtain the dynamics of these literary expressions. In addition, an ecocritical method was also used to see the direction of river-related literary expression in West Kalimantan's literature. The results show that the existence of rivers is an important pillar of people's life in West Kalimantan as emphasized through literary works.
\end{abstract}

Keywords: ecocritical meaning, river, expressions, and literature of West Kalimantan.

\begin{abstract}
ABSTRAK
Sungai merupakan bagian penting tata kelola sosial dan lingkungan masyarakat Kalimantan Barat dan menjadi penanda keberadaan sebuah komunitas. Sastra adalah gambaran dari tata kelola itu karena hidup dan berkembang sesuai dengan lingkungan sekitarnya. Relasi antara sastra dan sungai dapat dilihat melalui ungkapan di dalam ujaran sastra. Gambaran sungai di dalam sastra berubah seiring dengan waktu yang menyebabkan perbedaan ungkapan dalam ujaran sastra Kalimantan Barat dalam bentuk puisi. Tulisan ini menggunakan semiotikdinamik sebagai alat analisis untuk melihat ungkapan sungai dan juga terhadap perubahan ujaran sastra. Alat analisis ini digunakan untuk mendapatkan dinamika ujaran-ujaran sastra tersebut. Selain itu, ekokritik juga digunakan untuk melihat arah ujaran sastra terkait sungai di dalam sastra di Kalimantan Barat. Hasil penelitian menunjukkan bahwa keberadaan sungai merupakan pilar penting kehidupan masyarakat Kalimantan Barat, yang dalam hal ini dipertegas melalui karya sastra.
\end{abstract}

Kata kunci: ekokritik, sungai, ungkapan, dan sastra Kalimantan Barat. 


\section{A. PENDAHULUAN}

Kondisi geografis Kalimantan Barat memberikan ruang bagi tumbuhkembang imajinasi sebuah karya seni, tidak terkecuali karya sastra. Sungai merupakan penanda geografis utama Kalimantan Barat. Tradisi dan budayanya tidak lepas dari keberadaan sungai yang mengular panjang hingga ke pelosok. Misalnya, lagu Aek Kapuas merupakan salah satu bukti nyata pentingnya sungai bagi Kalimantan Barat. Lagu tersebut, dalam konteks Kalimantan Barat, menunjukkan bahwa sungai merupakan bagian penting lingkungan hidup Kalimantan Barat. Secara umum, lingkungan hidup itu memberikan pengaruh berarti bagi kehidupan, yang teraktualisasi dalam karya sastra.

Pengaruh lingkungan hidup Kalimantan Barat tergambar jelas dalam sungai. Sungai sejak lama menjadi tumpuan kehidupan, bahkan memberikan kemanfaatan untuk penelitian. Catatan ilmuwan Belanda, Nieuwenhuis, pada 1894 dimulai dari Pontianak, menyusuri Sungai Kapuas hingga ke hulu dan kemudian berjalan kaki melintasi Pegunungan Muller hingga ke Sungai Mahakam di Kalimantan Timur. Dari perjalanan itu, Nieuwenhuis memperoleh bahan berharga mengenai gambaran pedalaman Kalimantan seratus tahun lalu (Yusriadi dan Hermansyah 2003:129). Dari Sungai Kapuas sebagai lingkungan hidup, terlihat fungsinya dalam menopang aspekaspek kehidupan Kalimantan Barat.

Hal ini membuktikan bahwa Sungai Kapuas, terkait erat dengan masyarakat Kalimantan Barat. Suasana dan kondisinya selalu menjadi bagian dan memengaruhi lingkungan alam dan sosialnya. Demikian juga pada kesastraan Kalimantan Barat, keberadaan Sungai Kapuas menjadi ungkapan dan gambaran dari internalisasi kreativitas dalam karya sastra.

Kesastraan Kalimantan Barat bersentuhan erat dengan sungai sebagai gambaran kemaritiman dalam lingkungan sungai, justru tidak dengan lingkungan laut. Hanya uniknya, berdasarkan konvensi masyarakat Kalimantan Barat, "sungai" kerap disebut "laut". Lingkungan air hakikatnya terkait erat dengan kemaritiman. Sungai pun pada akhirnya bermuara ke laut. Dengan kata lain, sungai tidak bisa lepas dari laut yang memang harus dilalui saat bertandang ke sebuah wilayah di Kalimantan Barat dengan moda transportasi sungai.

Dalam konsep sastra maritim untuk konteks Kalimantan Barat, terdapat hubungan antara karya sastra dengan lingkungan sungai. Dengan demikian, kehidupan sastranya memang benar-benar ditopang oleh lingkungan yang melingkupinya, yaitu lingkungan sungai. Lingkungan dilestarikan oleh sastra melalui dokumentasi, dan lingkungan sendiri menjadi sumber imajinasi bagi sastra.

Membaca karya sastra sama halnya dengan memahami kehidupan (manusia) karena hubungan sastra dengan kehidupan sangat erat. Di dalam karya sastra tercermin ragam kehidupan, baik menyangkut hubungan manusia dengan sesama, manusia dengan dirinya sendiri, manusia dengan lingkungannya, atau manusia dengan Tuhannya (Suwondo 2011:1). 
Ekokritik sebagai cara mengetahui konstruksi hubungan manusia dan lingkungan, merupakan bagian dari membaca sastra. Lingkungan menjadi sumber konstruksi karya sastra yang ditransformasikan dalam wacana imajinasi sesuai apa yang dilihat dan dirasakan oleh sastrawan itu sendiri.

Menurut Lotman dalam Faruk (1994:47) sastra adalah sistem pemodelan tingkat kedua. Maksudnya, sastra merupakan sistem pemodelan yang ditumpangkan pada pemodelan tingkat pertama, yaitu bahasa. Maksud dari pemodelan itu sendiri adalah bahwa sastra merupakan suatu wacana yang memodelkan semesta yang tidak terbatas dalam satu semesta imajiner yang terbatas.

Sungai di Kalimantan Barat yang menjadi bagian dari semesta merupakan model yang dihadirkan oleh sastra. Sungai tersebut dihadirkan melalui teks sastra yang ditulis oleh para pengarang Kalimantan Barat. Sungai Kapuas atau anak-anak sungainya menjadi pemodelan sastra melalui bahasa sebagai pemodelan tingkat pertama.

Di sisi lain, Sungai Kapuas dan anak-anak sungainya juga merupakan sumber kebudayaan. Misalnya, gertak atau geretak yang dibangun karena keberadaan sungai. Geretak merupakan infrastruktur teknologi untuk menunjang kehidupan atas keberadaan sungai. Sistem peralatan hidup dan teknologi merupakan satu dari tujuh pokok kebudayaan (Emzir dan Rohman 2015:209). Sungai menjadi entitas sumber kebudayaan yang memengaruhi sistem kebudayaan turunannya. Dengan demikian, sungai berperan penting dalam pola kehidupan, yang membentuk pokok-pokok kebudayaan yang lain. Sebagai bagian dari pola kehidupan itu, sungai menjadi inspirasi, termasuk dalam sastra secara tidak sadar.

Keterikatan sungai dan sastra berkonteks Kalimantan Barat merupakan gambaran relasi pengarang dengan lingkungan sekitarnya. Persahabatan dengan alam dan kepedulian penyair atau sastrawan pada umumnya terhadap lingkungan sekitarnya telah menempatkan alam dan lingkungan sebagai sumber ilham yang tiada pernah ada habisnya (Mahayana 2005:165-166 ).

Oleh karena itu, fenomena sungai dengan segala problematika, baik menggembirakan maupun menyedihkan, masuk dalam catatan sastrawan Kalimantan Barat. Fenomena sungai yang dijadikan sumber imajinatif karya sastra merupakan sumber fakta yang mengalami proses internalisasi. Fakta telah mengalami penghayatan, pemaknaan, penilaian, lalu memasuki proses pengolahan, dan rekayasa sehingga fakta yang disajikan tidak lagi persis sama dengan fakta yang terjadi. Ia telah menjalani proses fiksionalisasi. Oleh karena itu, fakta itu menjadi fiksi. Ia bersifat fiksional (Mahayana 2005:360).

Sungai sebagai fakta pada gilirannya mengalami perubahan gambaran dalam bingkai sastra setelah mengalami proses internalisasi. Gambaran tersebut merupakan ungkapan tentang sungai yang berbeda-beda seiring fakta ruang dan waktu yang bergerak dalam ujaran sastra. Fakta sungai pasti tidak berubah, hanya pemaknaan fakta yang berubah 
sesuai kebutuhan sastra melalui proses internalisasi para sastrawannya.

Selanjutnya, ruang dan waktu menjadi pembeda jelas kisah sungai di Kalimantan Barat. Termasuk juga pengaruh yang ditimbulkan dari keberadaan sungai sesuai jarak ruang dan rentang waktu. Tidak kalah penting, sungai dapat menjadi cermin, justru untuk melihat masyarakat dalam konteks ruang dan waktu tertentu. Korelasi yang ada dan ditimbulkan merupakan kerangka holistik keberadaan sungai sebagai pembentuk kesastraan maritim.

Misalnya, saat sampan yang menyusuri parit yang terhubung dengan sungai dan sungai sendiri tercemar sampah, merupakan entitas sungai dalam wacana sastra. Sampan dan sampah akan menimbulkan kisah dengan kesan yang berbeda. Dengan sampan, sungai itu terkesan lestari, sedangkan dengan sampah justru memberikan kesan bahwa ekosistem sungai terganggu.

Secara faktual, penelitian yang dilakukan Fadiah Umar, Siti Nurisjah, dan Ricky Avenzora berjudul Identifikasi dan Rencana Pengembangan Kawasan Wisata Budaya Koridor Sungai Kapuas-Kota Pontianak memperlihatkan bahwa Sungai Kapuas memiliki potensi ekonomi, seperti tempat mata pencaharian dan pariwisata. keberadaan Sungai Kapuas memberikan arti bagi kehidupan masyarakat Kalimantan Barat secara meluas. Penelitian tersebut dimuat dalam Jurnal Lanskap Indonesia Volume 2 Nomor 1 2010.

Dampak berarti tersebut tampak pada hubungan antara sungai dan sastra dalam konteks Kalimantan Barat. Sungai dan sastra bagi Kalimantan Barat merupakan dua entitas yang membentuk sastra maritim. Kedekatan subtil dengan sungai berpengaruh besar kepada ujaran-ujaran sastrawan Kalimantan Barat, yang sekaligus menyampaikan kabarnya dari waktu ke waktu. Lagu daerah Aek Kapuas karya Paul Putra menjadi gambaran perubahan Sungai Kapuas.

Ungkapan sastra memiliki potensi memotret fenomena lingkungan saat ungkapan tersebut diproduksi. Di samping itu, sastrawan seringnya berpijak pada kondisi waktu itu sehingga apa yang dilihat dan rasakan dijadikan sumber pijakan. Sungai Kapuas dengan kondisi waktu itu dapat dipotret apa adanya melalui ujaran sastra.

Hal yang menarik adalah bagaimana ungkapan sungai dalam ujaran sastra karya para penulis Kalimantan Barat. Oleh karena itu, tujuan penelitian ini adalah mengetahui ungkapan sungai dalam ujaran sastra Kalimantan Barat seiring perubahan waktu. Sungai yang dimaksud adalah Sungai Kapuas sebagai sentral peradaban masyarakat Kalimantan Barat. Kemudian, puisi-puisi di beberapa antologi yang ditulis penulis Kalimantan Barat dijadikan data penelitian. Karya sastra terkait erat dengan dimensi ruang dan waktu, yang termasuk lingkungan hidup yang selalu mengalami perubahan dengan berjalannya waktu. Hal itu memicu perubahan ungkapan sastra terhadap lingkungan hidup sekitar.

Dalam Keseimbangan Lingkungan dalam Puisi Teratak Lima, Khairul 
Fuad mengupas kondisi lingkungan yang masih baik di Kalimantan Barat melalui puisi yang ditulis pada $1960-$ an. Penelitian ini diterbitkan dalam prosiding seminar yang diselenggarakan Fakultas Ilmu Budaya, Universitas Mulawarman Kalimantan Timur pada 24-25 Oktober 2017. Sebaliknya, penelitian Binar Kurniasari Febrianti, Lingkungan Alam dalam Singkawang Antologi Sajak Pradono, mengupas lingkungan dengan fokus pada perubahan kondisi sungai dari waktu ke waktu melalui karya sajak Pradono.

Sungai merupakan urat nadi masyarakat Kalimantan Barat dari dulu sampai sekarang sehingga ungkapan pada teks sastra merupakan kelaziman. Oleh karena itu, perlu pendekatan semiotik dalam mendedah makna ungkapan sungai itu. Sementara itu, semiotik mengarahkan makna ungkapan sungai dalam bingkai pengetahuan ekokritik sebagai alat analisis yang menjembatani antara sastra dan lingkungan alam sekitarnya. Sungai sebagai simbol masyarakat Kalimantan Barat dapat dipastikan mengalami perubahan sebagai bagian ekosistem lingkungan. Sementara itu, semiotik berupa telaah terhadap tanda tertuju pada kondisi sungai di Kalimantan Barat. Ekokritik merupakan kerangka pikir untuk membangun wacana terkait kondisi sungai tersebut. Selain itu, ekokritik dan sungai berelasi dengan lingkungan hidup dengan segala problematikanya. Pada gilirannya, tulisan ini diharapkan mampu mendedah makna ungkapan sungai sebagai bagian dari lingkungan alam yang rentan.

\section{B. METODE}

Penelitian ini menggunakan metode semiotika, terkait dengan ungkapan sungai yang terdapat tanda yang akan dikaji di dalam karya sastra pengarang Kalimantan Barat. Ungkapan sungai tersebut menghadirkan makna yang terkait dengan pengetahuan ekokritik. Dengan demikian, dinamika keberadaan sungai terlihat terkait dengan dinamika sosial melalui ungkapan sungai dalam ujaran sastra.

Menurut Pierce, logika (penalaran) melalui tanda-tanda memungkinkan untuk berpikir, behubungan dengan orang lain, dan memberi makna pada apa yang ditampilkan oleh alam semesta (Sudjiman dan Zoest 1996:1). Oleh karena itu, sungai di Kalimantan Barat merupakan bagian tanda dari alam semesta yang beragam, seperti gunung dan hutan. Alam semesta sebagai rangkaian kosmos memiliki dua sisi, yaitu makrokosmos dan mikrokosmos. Sungai bagian dari makrokosmos, sedangkan manusia merupakan mikrokosmos yang memiliki kemampuan menafsirkan tanda alam semesta. Terkait penafsiran (interpretant), maka tanda alam memberikan ruang tafsir, sedangkan manusia dengan sumber dayanya yang menafsirkan tanda alam itu.

Ungkapan sungai dalam sastra dapat dimaknai sesuai dengan keberadaan sungai di Kalimantan Barat sebagai ruang tafsir. Kemudian, upaya penafsiran merupakan pemaknaan terhadap kondisi sungai, melalui semiotik (perangkat metodologis dalam penafsiran) yang memberi saran kepada konsep ekokritik terkait sungai sebagai bagian alam semesta. 
Pemaknaan tersebut mengalami perubahan karena sungai sebagai tatanan alam semesta cenderung berubah sesuai kondisi dinamika sosial. Jadi, sungai merupakan ungkapan yang dimaknai melalui tanda pada deretannya yang terdapat di dalam karya sastra para sastrawan Kalimantan Barat.

Seperti telah disebut di atas, sebagai bagian lingkungan alam semesta, sungai berpotensi mengalami perubahan yang dapat ditelisik melalui diksi sastra. Dengan demikian, terdapat dua sisi pembahasan, yaitu ekologi dan sastra, maka diperlukan metode ekokritik sastra atau ekokritisisme. Ekokritisme bertujuan menganalisis teks yang difokuskan pada peran lingkungan hidup ke dalam sastra atau sebaliknya (Endraswara 2016:29).

Karya sastra adalah rangkaian kata dan frasa yang merupakan objek semiotik yang dianggap sebagai sistem tanda. Pemilihan tanda itu sesuai dengan tujuan penelitian ini terkait ujaran sungai. Kemudian, ujaran tersebut dianalisis dengan mendasarkan konsep ekokritik.

Dengan demikian, sinergitas dari metode ini adalah relasi objek, metode yang digunakan, dan makna yang ditentukan dari ungkapan sungai dalam ujaran sastra Kalimantan Barat. Relasi ketiganya tersebut merupakan upaya sistematisasi untuk mengetahui makna ungkapan sungai dengan tanda-tanda di dalamnya untuk mengerucutkan relasi sastra dan lingkungan hidup sekitarnya. Tentunya, lingkungan hidup yang dimaksud adalah sungai yang keberadaannya tidak bisa terpisah dari masyarakat Kalimantan Barat. Sebagai bagian dari lingkungan, sungai selalu mengalami fluktuasi sesuai perubahan lingkungan yang pernah mengalami keseimbangan atau sebaliknya, ketidakseimbangan.

Sementara itu, terkait penelitian terdahulu masih belum banyak ditemui kajian dengan dasar konsep ekokritik. Setidaknya dalam konteks Kalimantan Barat terdapat dua penelitian yang telah disebut sebelumnya. Dua penelitian itu menyarankan kepada pendekatan ekokritik. Penggunaan semiotik sebagai metode untuk mengetahui tanda, sedangkan ekokritik sebagai metode analisis terhadap tanda yang telah diketahui.

\section{HASIL DAN BAHASAN}

Diskusi seputar sungai tidak bisa dihindarkan dari pembahasan lingkungan sebagai bagian dari ekosistem yang lebih luas. Selain itu, sungai merupakan ekosistem lingkungan Kalimantan Barat yang berperan penting membentuk tradisi maritim. Sungai Kapuas merupakan entitas lingkungan yang sangat dekat dengan kehidupan Kalimantan Barat. Kedekatan ini kemudian membentuk cara pandang terhadap sungai tersebut.

Cara pandang ini tidak terlepas juga dari kondisi lingkungan yang menyertai pada waktu itu. Lingkungan yang seimbang akan memengaruhi ungkapan sebagai cara pandang di dalam karya sastra, sedangkan kondisi sebaliknya memiliki dampak yang berbeda. Dua keadaan lingkungan berbeda ini ber-pengaruh terhadap ungkapan sungai di dalam karya sastra dalam khazanah kesastraan Kalimantan Barat. 
Dua sisi hasil pembahasan ini, yaitu keseimbangan-ketidakseimbangan, dikarenakan temuan puisi-puisi ini menyarankan kepada ungkapan sungai yang menggambarkan dua perubahan tersebut. Di sisi lain, keseimbangan dan ketidakseimbangan dipilih karena terkait alam semesta yang berpotensi mengalami perubahan seiring perubahan waktu.

\section{Keseimbangan}

Ungkapan sungai pada karya sastra di bawah ini memberikan gambaran yang menggembirakan. Gambaran tersebut menunjukkan bahwa lingkungan sekitar masih terdapat keseimbangan sehingga ujaran sungai masih diproduksi dalam ujaran positif (positive speech). Puisi karya Suhaimi Ladjim di bawah diproduksi oleh kelompok sastra yang menamakan dirinya Teratak Lima, kelompok yang muncul pada era 1960 -an. ${ }^{1}$

Perkenalan II

Sambas Negeriku

Sungai, jembatan, bulan

Adalah kota yang lahir dalam paduan Sampan, jaka, perawan

Adalah cinta yang cair dalam kerinduan

${ }^{1}$ Suhaimi Ladjim merupakan pegiat sastra yang tergabung dalam kelompok sastra bernama Teratak Lima yang pernah mewarnai perkembangan sastra Kalimantan Barat. Nama-nama lain pernah juga tercatat sebagai pembesut dan pengusung Teratak Lima, seperti Gusti Mulya, Sirri Rusdagani, Boestami Arif, dan lain-lain. Orang-orang tersebut pernah meramaikan panggung sastra Kalimantan Barat meski masih jarang diketahui kiprahnya (Fuad 2017:109-110).
Manusia dan buminya

Lebur pada nafas-nafas yang sama

Cerita dan nyanyiannya

Subur tumbuh disetiap dadanya

-siapa terkenang

Pada malam-malam begini tenang

Nenek berkisah tentang si dara mendung

Atau tentang tujuh puteri saudara

kandung

Siapa teringat

Pada malam-malam begini lembut

Nenek berlagu si batu ballah

Tentang kasih ibu dan anak-anak yang terpisah

Bulan bersinar atas jembatan

Nenek bercerita sepanjang malam

Sampan melancar atas sungai

Nenek berdendang berlagu sansei.

(Fuad 2017:113)

Puisi itu ditulis pada 1960-an. Puisi tersebut mengungkap tentang kehidupan Kota Sambas, termasuk kehidupan seputar sungai. Kota Sambas dialiri juga oleh sungai bernama Sungai Sambas. "Sungai, jembatan, bulan//Adalah kota yang lahir dalam paduan//Sampan, jaka, perawan//Adalah cinta yang cair dalam kerinduan" adalah gambaran kota Sambas yang dekat dengan lingkungan sungai, sebagaimana mayoritas beberapa kota di Kalimantan Barat.

Sungai adalah aliran air yang besar (biasanya buatan alam); kali: sungai itu dapat dilayari sampai ke pedalaman (KBBI luring). Sebagai ungkapan, sungai tersebut dibangun melalui tanda-tanda yang terdapat pada puisi Suhaimi Ladjim. Pada bait pertama, terdapat kata jembatan dan 
bulan yang merupakan tanda-tanda yang membangun ungkapan sungai. Jembatan merupakan infrastruktur yang melintasi sungai untuk menghubungkan dua wilayah. Sementara itu, bulan bagian semesta yang muncul pada malam hari sebagai tanda kedamaian.

Biasanya bulan dimaknai sebagai keindahan dan kedamaian. Dari dua tanda ini, sungai digambarkan dalam kondisi masih baik. Hal ini dikuatkan dalam larik selanjutnya, //adalah kota yang lahir dalam paduan//. Sungai bersama jembatan dan rembulan berpadu membangun kota, yaitu Kota Sambas.

Ungkapan sungai masih dalam kondisi baik terdapat pada tanda-tanda yang dihadirkan pada bait terakhir puisi Suhaimi Ladjim. //Sampan melancar atas sungai//. Sampan sebagai moda transportasi sungai dikayuh dengan mudah berjalan membelah sungai. Melancar berarti bergerak laju dengan cepat; meluncur di atas permukaan air yang tenang. Dengan demikian, sungai dalam ungkapan yang masih terjaga dan cenderung alami.

Tanda-tanda yang membangun ungkapan sungai di dalam puisi tersebut memberikan isyarat bahwa sungai masih terjaga secara alamiah. Tandatanda tersebut juga memengaruhi ujaran lainnya, seperti "Manusia dan buminya// Lebur pada nafas-nafas yang sama," mengisyaratkan bahwa lingkungan alam Sambas masih seimbang ekosistemnya. Keseimbangan itu ditandai dengan sampan masih lancar membelah sungai.

Ungkapan sungai yang dibangun oleh sampan, jembatan, dan rembulan sebagai tanda dalam puisi Suhaimi
Ladjim, menyatakan bahwa sungai masih dalam keadaan seimbang. Sungai sebagai bagian lingkungan hidup masih terawat sesuai ungkapan sungai yang diproduksi oleh Suhaimi Ladjim dalam puisinya.

Romantika dan problematika sungai selalu mengiringi perjalanan Kalimantan Barat, yang terdapat pada berbagai narasi, seperti pada narasi sastra. Ahmad Asma dZ memiliki pandangan yang sama dengan Suhaimi Ladjim. Perbedaannya ada pada rentang waktu. Puisi Asma ditulis pada 2005 dalam sebuah antologi yang berjudul Ruang \& Waktu Rangkaian Potret Kata tentang Kehidupan, Cinta, Keindahan, dan Rasa Syukur. Hanya saja, ungkapan sungai di dalam puisinya menggambarkan kerinduan suasana sungai yang tidak pada kondisi lingkungan secara alamiah.

Dalam antalogi puisi karya Asma, ungkapan sungai terdapat pada cuplikan, baik puisinya berjudul Maukah Engkau Menunggu maupun Pontianak Satu. Suasana romantis diungkapkan untuk menggambarkan sungai sebagai kerinduannya di saat melakukan perjalanan, seperti pada cuplikan Maukah Engkau Menunggu:
Karena Salju Gunung Bernina akan mencair pula nantinya. Turun ke Sungai Rheine bermuara di laut utara Namun, air sungai Kapuas yang kuminum. Seolah melantunkan Lalu untuk pulang. (Asma dZ 2008:10) 
Kemudian, pada cuplikan Pontianak Satu:

Aku rindu sungaiku, Sungai yang akan membuatku teringat kemanapun aku berada Sungai yang airnya mampu membuang dahaga rasa akan jiwa

Aku rindu sungaiku, Untuk menahan gemercik buihnya, untuk

Bersetubuh dengan kedamaian dalamnya

Mengayuh sampan membelahnya

Melihat sang surya tenggelam diantaranya. Atau hanya sekedar Duduk untuk bercengkerama. (Asma dZ 2008:12)

Ungkapan sungai pada dua cuplikan puisi di atas memperlihatkan bahwa Asma tampak ingin sekali menggambarkan suasana Sungai Kapuas. Tanda-tanda di dalamnya menggambarkan kerinduan saat melakukan pemetaan lintas budaya. Meskipun ditemui Sungai Rheine dalam proses tersebut, Sungai Kapuas tetap menyulut kerinduan. Baginya, Kapuas adalah kehidupan.

Sungai Rheine merupakan sungai terpanjang di Eropa, demikian juga Sungai Kapuas terpanjang di Indonesia. Sungai Rheine panjangnya 1.233 kilometer, sedangkan Sungai Kapuas panjangnya 1.143 kilometer. Meskipun berbeda pajangnya, Air Sungai Kapuas tetap menjadi penanda untuk kembali pulang. Menurut kepercayaan umum masyarakat Kalimantan Barat, kalau sudah minum air Kapuas, ke manapun pergi akan kembali lagi.
Kemudian dalam Pontianak Satu, ungkapan sungai menunjukkan suasana Sungai Kapuas dengan kerinduan// Sungai yang akan membuatku teringat kemanapun aku berada//. Ungkapan sungai yang mengacu kepada Sungai Kapuas tidak dapat terlepas dari kehidupan masyarakat Kalimantan Barat. Keberadaannya merupakan bagian geografis penting dan memengaruhi kehidupan sosial Kalimantan Barat.

Sungai Rheine dan air kapuas sebagai tanda dalam ungkapan sungai yang membangun kerinduan terhadap Sungai Kapuas sebagai bagian lingkungan hidup. Sungai Kapuas dengan segala kondisi dan habitat lingkungan hidup, selalu memantik rindu dalam puisi Ahmad Asma dZ saat berada di tempat manapun.

\section{Ketidakseimbangan}

Beberapa tahun berikutnya terjadi ketidakseimbangan alam yang mengubah gambaran sungai yang terekam dalam ungkapan-ungkapan terhadap sungai yang sudah tidak alami lagi dalam ujaran kesatraan Kalimantan Barat. Terkait ketidakseimbangan pada sungai sebagai ungkapan banyak terdapat dalam kesastraan Kalimantan Barat kontemporer. Ungkapan ketidakseimbangan sungai sering dibicarakan para sastrawan Kalimantan Barat sebagai gambaran kondisi sungai sebenarnya.

Pontianak dalam Kenangan I

Wyaz Ibn Sinentang

Menandai malam di kotamu menjejak langkah-langkah

Sepanjang jalan berkayuh masa silam 
Berjejar warung tenda menyubit selera makan

Bergerombol anak-anak muda Menyantap gairah eksotis wajah metropolis

Menari-nari cahaya lampu jalanan Mengubah imaji tentang kenangan lalu

Sepanjang mata memandang deretan gedung-

Gedung megah membutakan rasa

Menyusuri pagi di kotamu tak akan kudapati lagi

Asrinya suasana alam yang menentramkan hati

Parit-parit berubah fungsi

Tak ada lagi senda gurau para gadis mencuci pakaian,

Tak ada lagi bocah-bocah cilik terjun dari jembatan,

Tak ada lagi pedagang sampan

berseliweran

Tawarkan sayur-mayur, buah-

buahan, atau

Hasil bumi lainnya,

Tak ada lagi ikan-ikan yang menyapa para pengail musiman

Merapati siang di kotamu membuat hati panas

Simpang-siur kendaraan berjejal

Menahan laju traffic light

Kemacetan menjadi rutinitas

Debu keringat menyatu memburu angan

Sementara deru angin tertahan

Tak kudapati lagi pemandangan tahun tujuh puluh lima

Jalanan yang lengang

Udara segar membalur nafas

Dan anak-anak sekolah pulang sekolah bersepeda ria
Menggenggam sore di kotamu fikir

kian trenyuh

Tak pernah lagi kulihat adik-adik

kecil

Bermain petak umpet,

Galah panjang,

Kejar bulan,

Meninting guli atau dakocan,

Juga memutar tali rinso

Semua telah tergantikan dengan

Bermain game online, chatting,

facebook

Kemajuan zaman telah mengubah

budaya

Yang ada tinggal kenangan terbuang

Sepanjang hariku di kotamu tak

ubahnya

Bagai musafir kehilangan kata-kata

Menahun kelu rindu pada garis

lampau-mu

Pontianak, Januari 2011.

(Pradono ed. 2012:43-44)

Wyaz Ibn Sinentang menggambarkan Kota Pontianak yang telah mengalami perubahan dari masa yang pernah dialaminya pada 1975 . Menariknya, pada puisi tersebut digambarkan tradisi sungai yang memang sangat dekat dengan kehidupan Pontianak dan juga Kalimantan Barat. Tidak terkait langsung dengan sungai, tetapi tentang parit sebagai bagian dari tradisi sungai. Keberadaan parit tidak terlepas dari sungai.

Terdapat beberapa tanda yang menyiratkan ketidakseimbangan paritparit di Pontianak dikarenakan telah berubah fungsi. Senda gurau gadis, anak-anak bermain air, dan para pedagang yang berjualan sudah tidak 
bisa ditemui lagi di parit-parit Pontianak. Tanda-tanda tersebut memberikan isyarat bahwa parit telah mengalami perubahan signifikan. Fungsi budaya dan fungsi ekonomi sudah berubah seiring perubahan masa.

Pada 1975 hal yang tadi disebutkan masih terlihat. Secara semiotis, kegembiraan gadis-gadis dan bocahbocah serta transaksi dagang para pedagang terwujud saat parit-parit masih dalam keadaan baik. Dalam ujaran puisi ini, yang dijadikan ungkapan adalah parit yang merupakan ekosistem keberadaan sungai di Kalimantan Barat.

Seiring perubahan waktu, lingkungan alam telah mengalami kerusakan, misalnya, penyempitan, pengendapan, dan sampah pada parit-parit di Pontianak. Ungkapan parit dalam ujaran puisi Sinentang mengisyaratkan ujaran negatif. Kemudian, ungkapan tersebut didukung oleh ujaran-ujaran lain yang mengacu kepada perubahan-perubahan Pontianak yang telah kehilangan keramahannya, berbeda dengan kondisi di masa lampaunya.

Tanda bentuk frasa, seperti senda gurau gadis, bocah main air, dan para pedagang berseliweran di parit tidak ditemui lagi, menjadi pertanda perubahan sungai sebagai lingkungan hidup. Tanda-tanda dalam ungkapan sungai memberikan makna bahwa lingkungan hidup sungai telah mengalami perubahan berarti dalam puisi Wyaz Ibnu Sinentang.
Sungai Singkawang

Menyusuri sigar

Dari gertak rusen hingga gertak agen

Hanya tersaksikan air permukaan

Berubah rupa jadi tabah daratan

Bertumbuh rumput dan ilalang

Di rusuk dan perut sungai

Singkawang

Entah kapan lagi

Biak-biak Singkawang

Nikmati masa kecil merenangi

sungai Singkawang

Mendarat tanpa gatal korengan

Para tetamu habiskan hari menatap

bersih

Dan sejuk mata di sepinggir sungai

Singkawang

Entah kapan lagi kubisa amati lundu dan ikan kebali

Berenang bebas sembari elakkan mata kail

Pemancing yang bertengger di motor ikan

Pangkalan Sutianso

Entah kapan kita kembalikan sungai

Singkawang

Jadi kebanggan tanpa celaan

Dan wabah korengan

Singkawang, 2011.

(Pradono 2017:154)

Pradono menggambarkan kondisi Sungai Singkawang yang telah kehilangan kealamiahannya. Sungai tersebut mengalir sepanjang gertak Rusen sampai gertak Agen. Gertak merupakan jembatan yang melintasi sungai atau jembatan kecil memanjang pada susur pinggir sungai. Gertak memberikan gambaran khas sebuah infrastruktur yang berada di Kalimantan 
Barat. Menurut Soedarto, gertak merupakan jawaban yang diberikan Belanda atas Pontianak yang berkultur sungai (Fuad 2016:149). Pontianak adalah representasi wilayah di Kalimantan Barat, yang umumnya berkultur sungai.

Sungai sebagai tanda telah memberikan isyarat melalui ungkapan yang diproduksi oleh Pradono. Tandatanda ketidakseimbangan tergambar dalam puisi Sungai Singkawang, sungai telah mengalami sendimentasi. Ketidaklayakan terdapat pada sungai di Singkawang, berubah menjadi daratan yang ditumbuhi oleh rumput dan ilalang.

Sungai Singkawang tidak dapat dimanfaatkan secara maksimal sebab telah terjadi ketidakseimbangan. Di sisi lain, ungkapan-ungkapan sungai Singkawang merupakan kegelisahan sekaligus kekecewaan Pradono terhadap kondisi yang tidak seperti dulu lagi. Bait-bait berikutnya menandakan bahwa ungkapan pada sungai memberikan isyarat bahwa manfaatnya dapat diambil, seperti anak-anak bebas berenang tanpa dampak kesehatan yang ditimbulkan.

Jenis-jenis ikan, seperti lundu dan kebali, dapat terlihat karena airnya jernih dan para pemancing menanti keberuntungan mata kailnya disambar sambil bertengger di motor ikan di pangkalan Sutianso. Sungai Singkawang sebagai tanda dalam teks sastra telah membangun struktur yang tidak otonom atau tidak berdiri sendiri terlepas dari unsur-unsur di luarnya (Effendy 2006:101). Ungkapan kegelisahan dan kekecewaan Pradono terhadap Sungai Singkawang menan- dakan adanya unsur-unsur lain yang mempengaruhi, seperti sedimentasi.

Ungkapan kegelisahan terhadap sungai di Singkawang dapat dijumpai dari tanda-tanda yang dihadirkan oleh Pradono, yaitu gertak Rusen, gertak Agen, dan pangkalan Sutianso. Keberadaan tanda-tanda itu mengisyaratkan sungai dan kondisi saat puisi tersebut ditulis. Keadaan dan sungai yang dimaksud adalah ketidakseimbangan ekosistem pada satuan ekologi bernama sungai.

Dari ungkapan melalui tanda sungai dapat dipahami bahwa Sungai Singkawang telah mengalami kerusakan lingkungan hidupnya secara ekokritik. Ekologi di dalamnya telah mengalami ketidakseimbangan, yaitu tidak ada hubungan timbal balik antara alam sekitar dan makhluk hidup. Sedimentasi sungai diakibatkan oleh faktor-faktor yang tidak menguntungkan. Sirkulasi aliran sungai terganggu sehingga makhluk hidup tidak bisa bertahan hidup.

Kelangkaan ikan endemik dan sedimentesi merupakan ungkapan sungai yang menyatakan bahwa Sungai Singkawang sebagai lingkungan hidup telah mengalami ketidakseimbangan lagi dalam ekosistem lingkungan. Sebagai orang Singkawang, Pradono menunjukkan kepedulian terhadap lingkungan hidup Sungai Singkawang yang mengalami ketidakseimbangan pada puisinya.
Kurindukan Kapuasku
Kurindukan kampungku yang dulu
Semasa kanak berebutan merekam
jejak
Menangkap belalang di padang luas 
Berenang bebas menyusuri Kapuas

Melepas penat setelah seharian menyeruputi

Wejangan tentang negeri antahberantah

Dalam buku-buku tua yang dikirim ke sekolah

Kurindukan sungaiku dulu Tempat biasanya ayah mengajakku Menyaksikan ia pamer kebolehan Menebar jala Menangkap udang dan seluang Ah, kini hanya kenangan Tinggal sepotong kenangan Karena parit-parit kian menyempit Menyembunyikan berjuta nostalgia Tentang sepasang slomang Yang sedang dimabuk birahi Atau sekumpulan gendang-gendis yang memberi tanda Bahwa sungaiku masih segar Seperti dulu

Belum lagi tercemar

Pontianak, 13 Januari 2011.

(Pradono ed. 2012:46)

Puisi di atas adalah karya Yophie Tiara. $^{2}$ Puisi tersebut terdapat pada antologi Cahaya Khatulistiwa di Taman Kata, bersama pegiat-pegiat sastra Pontianak. Peluncurannya adalah dalam rangka memperingati peristiwa titik kulminasi Pontianak.

Kapuas menjadi tanda yang dihadirkan Tiara sebagai sungai yang menyusuri, tidak hanya Kalimantan Barat, tetapi Kalimantan secara keseluruhan. Kapuas menyimpan

2 Ia menulis antologi cerpen Nol Derajat bersama Amrin Zuraidi Rawansyah dan Pay Jarot Sujarwo. cerita panjang dari hilir sampai ke hulunya. Cerita mulai dari kondisi sosial masyarakat Sungai Kapuas hingga kekayaan hayati yang terdapat dan terkandung di dalamnya sebagai gambaran keseimbangan.

Sementara itu, dalam puisi Kurindukan Kapuasku dihadirkan ungkapan cerita tentang ketidakseimbangan pada Sungai Kapuas dalam ujaran sastra. Kata rindu menjadi tanda pada judulnya sebagai ungkapan ketidakseimbangan. Di dalam KBBI disebutkan bahwa kata "rindu" berarti sangat ingin dan berharap benar terhadap sesuatu; memiliki keinginan yang kuat untuk bertemu (hendak pulang ke kampung halaman).

Diksi rindu dapat dipahami sebagai gambaran terhadap yang dilihat atau dirasakan sekarang dengan yang dilihat atau dirasakan pada masa lalu. Aku (penyair) tampaknya merindukan sungai pada masa kecilnya ketimbang masa dewasanya.

Kurindukan sungaiku dulu

Tempat biasanya ayah mengajakku

Menyaksikan ia pamer kebolehan

Menebar jala

Menangkap udang dan seluang

Ah, kini hanya kenangan

Tinggal sepotong kenangan

Karena parit-parit kian menyempit

Menyembunyikan berjuta nostalgia

Tentang sepasang slomang

Yang sedang dimabuk birahi

Atau sekumpulan gendang-gendis

yang memberi tanda

Bahwa sungaiku masih segar

Seperti dulu

Belum lagi tercemar 
Dalam puisi di atas terdapat paradoks, yaitu tentang "ayah aku" yang piawai saat menjala udang dan seluang dan kepiawaian ayahnya yang menjadi kenangan. Kepiawaian ayahnya tersebut didukung oleh keberadaan lingkungan sungai yang masih kondusif dengan adanya udang dan ikan yang masih melimpah di sungai.

//Ah, kini hanya kenangan// larik puisi menjadi ungkapan atas keberadaan sungai dengan segala aktivitasnya yang kini sulit dilakukan lagi atau tidak dapat ditemui lagi. Ungkapan merupakan kekecewaan dengan diksi "ah", yang menyatakan perasaan kecewa, menyesal, keheranan, tidak setuju. Kecewa kepada aktivitas lalu yang sulit dilakukan lagi di sungai pada masa kini.

Segala nostalgia terpaksa menjadi kenangan seiring ketidakseimbangan lingkungan, terutama sungai dan yang terkait, seperti parit. Karena menyempitnya parit, aktivitas dulu sulit dilakukan lagi. Sekumpulan gadis masih beraktivitas di sungai menjadi tanda bahwa sungai masih segar seperti dulu, belum tercemar.

Ayah aku dan kenangan merupakan bagian ungkapan sungai yang bermakna bahwa lingkungan hidup sungai telah mengalami ketidakseimbangan. Ungkapan sungai tersebut diproduksi oleh Yophie Tiara untuk menandakan kerusakan lingkungan hidup sungai dalam puisinya.

Ekosistem sungai pada masa lalu sudah tidak dapat ditemui lagi di masa kini. Sungai telah berubah seiring perubahan sosial dan lingkungan. Pertumbuhan sosial dan kerusakan lingkungan berdampak pada keberadaan sungai yang terkait erat dengan tatanan sosial masyarakat Kalimantan Barat.

Parit sebagai bagian dari sungai sering menjadi sumber acuan dalam mengembangkan ide kesastraan Kalimantan Barat. Selain sungai, parit atau kanal merupakan infrastruktur wilayah Kalimantan Barat, terutama Kota Pontianak.

Ketika membangun Pontianak, pemerintah kolonial Belanda sangat memperhatikan kultur wilayah Pontianak yang basah dan berawa. Oleh karena itu, Belanda merasa perlu membangun kanal-kanal yang mengelilingi Pontianak agar dapat mengatasi curah hujan tinggi dan pasang air laut (Fuad 2016:235). Terkait parit terdapat cuplikan puisi Zailani Abdullah (1955-2019) berjudul Cerita Sebuah Kota

Dari mana lagi kumau bercerita Tentang Kota Seribu Parit

Tentang satwa yang menawan

Dia hanya melihat semuanya

Lewat photo yang mulai buram

Dan memaknainya sendiri

Tentang parit yang dapat dilalui sampan

Tentang kicau burung yang merdu

Tentang orang hutan dan enggang gading

Di hatinya ada selaksa tanya Yang kuketahui pasti, di mana. (Basuki ed. 2015:45)

Abdullah bercerita tentang Pontianak yang disebutkan dalam larik puisinya //tentang Kota Seribu Parit//. Parit tidak dapat dipisahkan dengan keberadaan sungai, terutama 
Sungai Kapuas jika terkait dengan parit yang mengelilingi Kota Pontianak.

Pada masanya, parit dapat dikatakan sebagai urat nadi kehidupan masyarakat Pontianak. Di antaranya sebagai prasarana transportasi manusia dan barang dari satu tempat ke tempat lain di wilayah sekitar.

Kejayaan parit pada masa lalu dapat dipahami karena ekosistem lingkungan yang masih terjaga, misalnya masih bersih dari sampah. Buktinya, //tentang parit yang dapat dilalui sampan// dalam larik puisi Abdullah. Situasi ideal sebelum adanya reoreintasi transportasi darat melalui pembangunan yang menekankan pada akses jalan darat.

Kejayaan parit sebagi ungkapan sungai yang tidak ditemui lagi memberikan makna bahwa lingkungan sungai telah tidak seimbang. Zailani Abdullah (1955-2019) pernah merasakan kejayaan parit dijadikan ungkapan sungai untuk mengungkapkan kerusakan lingkungan sungai di dalam puisinya.

Di sisi lain, keberadan parit di Pontianak tidak terlepas dari Tanah Seribu (Duizend Vierkanten Paal) yang dibangun VOC pada 5 Juli 1779. Tanah Seribu ini dikelilingi oleh paritparit selebar tiga hingga lima meter. Pembuatan parit-parit sengaja diperlebar menjadi kanal (gracht). Selain sebagai batas areal, kanal ini juga berfungsi sebagai sarana transportasi, sirkulasi air di sekitar wilayah Tanah Seribu, mencegah banjir bahkan juga sebagai salah satu bentuk pertahanan untuk keamanan kota (Asma dZ 2013:45).
Dengan demikian, sungai dan parit merupakan bagian yang tidak terlepas dari kehidupan masyarakat Kalimantan Barat secara keseluruhan. Ungkapanungkapan sungai, termasuk parit, dapat dipahami sebagai keniscayaan dalam karya sastra untuk menggambarkan suasana kebatinan masyarakat. Bagi sastrawannya sendiri dapat dinilai sebagai kesadaran diri terhadap masyarakat dan lingkungannya.

Ungkapan sungai yang menggambarkan ketidakseimbangan yang dialami sungai terdapat juga pada puisi Nano L. Basuki berjudul Sungai Kami Menangis Lagi. Basuki menggambarkan kerusakan lingkungan sungai yang dipicu oleh eksploitasi melalui penambangan emas. Kegiatan penambangan ini pernah marak di wilayah Kalimantan Barat dan membawa petaka bagi sungai yang dieksplotasi untuk mendapatkan emas yang diperkirakan terdapat di dalamnya. Termasuk maraknya PETI yang mengganggu keseimbangan ekosistem sungai dan kemudian dilarang oleh pemerintah setempat.

Sungai Kami Menangis lagi

Usai dongpeng hantam celah batu

Tempat sembunyi emas murni

Sungai kami menangis lagi

Mata air layu

Hidup pun tak sebening pagi

Sungai kami menangis lagi

Ikan lari ke hulu

Duka semakin beku

Sungai kami menangis lagi

Monterado 2010-Singkawang 2011.

(Basuki 2012:61) 
Secara literal, dompeng merupakan serapan dari Dongfeng, sebuah perusahaan utama yang menghasilkan berbagai macam kendaraan bermotor yang bermarkas di Wuhan Provinsi Hubei Tiongkok. Akan tetapi, di dalam masyarakat Kalimantan Barat dompeng dipahami sebagai mesin diesel untuk membantu memperlancar pekerjaan, termasuk digunakan untuk menambang emas di sungai.

Selanjutnya secara semiotik, dompeng tidak hanya dimaknai sebagai alat mekanik, tetapi sarana yang berpotensi merusak kualitas sungai sebagai lingkungan hidup. Alat dompeng digunakan sebagai alat penyedot bahan tambang untuk emas beberapa gram dalam kegiatan penambangan emas di aliran Sungai Kapuas. Dompeng bukan semata sarana bantu kegiatan demi efektif dan efisien, melainkan bagian kontribusi kerusakan habitat Sungai Kapuas. Pelarangan PETI menjadi fenomena yang menjadikan alat bantu dompeng dalam ungkapan sungai sebagai tanda ketidakseimbangan yang dialami Sungai Kapuas dalam puisi Nano L. Basuki.

Sebuah puisi pendek Ilham Setia dalam antologinya berjudul Kama menunjukkan ungkapan kondisi Sungai Kapuas dengan beban lingkungan yang ditanggungnya. Sampah menjadi problematika lingkungan, yang mencemari Sungai Kapuas. Keberadaan sampah merupakan persoalan seiring perkembangan populasi masyarakat yang semakin meningkat. Puisinya sebagai berikut.
Anak Kapuas

Catatan anak sungai

Ketika ngapar antara debur berita

Aku anak Kapuas

Merintih lirih cemas

Sampah menari ganas

Sesakkan nafas

Mei 2013. (Setia 2014:27)

Puisi di atas mengungkap tentang kondisi memprihatinkan yang melanda Sungai Kapuas, terutamanya sampah yang menjadi problem setiap masyarakat, apalagi wilayahnya yang dilalui oleh sungai. Ngapar adalah aktivitas mencari barang yang masih bisa digunakan di tengah tumpukan sampah yang terbawa arus sungai (Setia 2014:27). Kegiatan ini menjadi persoalan saat ditemui volume sampah yang semakin menumpuk terbawa arus. Di sisi lain, ngapar tidak diartikan secara harfiah, melainkan dimaknai lain sebab diikuti dengan diksi "debur berita". Frasa ini dimaknai sebagai mencari berita Kapuas di antara banyaknya informasi.

Ungkapan sungai yang diproduksi Ilham Setia menggambarkan orang yang memiliki kedekatan dengan Kapuas yang merasa sangat khawatir tentang kondisi ketidakseimbangannya. Diksi "anak Kapuas" menunjukkan kedekatan dengan Kapuas yang diungkapkan seperti hubungan anak dan orang tua. Sungai Kapuas merupakan penanda sumber yang mengalirkan peradaban Kalimantan Barat dari dulu sampai sekarang. 


\section{SIMPULAN}

Ungkapan sungai berupa kata-kata yang memang akrab dengan keberadaan sungai, seperti sampan, jembatan, dan jenis ikan, menjadi wahana untuk memberikan makna terhadap kondisi lingkungan hidup sungai. Demikian juga, hubungan emosional terhadap keberadaan sungai menjadi bentuk ungkapan sungai untuk memaknai kondisi sungai bagian lingkungan hidup.

Hal yang perlu disikapi pada penelitian ini adalah penguatan sungai sebagai sumber khazanah kesastraan Kalimantan Barat. Sastra dijadikan aspek untuk memperkuat posisi sungai sebagai posisi sentral, baik secara geografis, ekonomis, maupun sosiologis. Oleh karena itu, dibutuhkan penelitian lanjutan untuk menunjukkan fungsi kompleks pada sungai dengan basis karya sastra.

Keberadaan sungai dengan keterkaitannya yang masih berfungsi pada masa lalu menjadi produksi untuk membangun ungkapan sungai. Ungkapan sungai seperti itu yang bermakna bahwa keberadaan lingkungan hidup sungai sudah mengalami ketidakseimbangan.

Dalam kondisi keseimbangan, digambarkan kondisi sungai melalui ujaran-ujaran eksotik dalam puisi, keindahan dengan segala panorama aktivitasnya. Dalam kondisi ketidakseimbangan, sungai digambarkan penuh polusi, baik lingkungan maupun sosial. Alih fungsi sungai dikarenakan orientasi ke darat melalui pembangunan memicu sisi keberadaan sungai yang terabaikan. Eksploitasi sungai melalui pertambangan memicu karya sastra Kalimantan Barat yang menggambarkan lingkungan sungai telah rusak, baik ekosistem maupun sisi eksotisnya. Oleh karena itu, penelitian yang sama melalui genre sastra lain dapat diupayakan.

Ungkapan sungai di dalam karya sastra Kalimantan Barat memberikan makna tentang kondisi sungai yang mengalami perubahan seiring perjalanan waktu. Sebagai bagian dari lingkungan hidup alam semesta, sungai mengalami dua perubahan, yaitu seimbang (terjaga habitatnya) dan tidak seimbang (terganggu habitatnya).

Ungkapan sungai dalam karya sastra menjelaskan hubungan timbalbalik antara sastra dan lingkungan hidup. Relasi timbal-balik itu merupakan konsep di dalam wacana ekokritik di saat sastra dikaitkan dengan keberadaan lingkungan hidup.

\section{DAFTAR SUMBER}

Asma dZ, Ahmad. 2008. Ruang \& Waktu Rangkaian Potret Kata tentang Kehidupan, Cinta, Perjalanan, Keindahan, dan Rasa Syukur. Yogyakarta: Bukulaela.

Asma dZ, Ahmad. 2013. Pontianak Heritage dan Beberapa yang Berciri Khas. Pontianak: Literer Khatulistiwa.

Basuki, Nano L. 2012. San Kew Djong Kumpulan Puisi. Pontianak: Deepositive.

Basuki, N.L., ed. 2015. Bayang-Bayang Tembawang Antologi Puisi. Pontianak: Pijar Publishing. 
Effendy, Chairil. 2006. Sastra Sebagai Wadah Integrasi Budaya. Pontianak: STAIN Pontianak Press.

Emzir dan Saifur Rohman. 2015. Teori dan Pengajaran Sastra. Jakarta: Raja Grafindo Persada.

Endraswara, Suwardi. 2016. Ekokritik Sastra Konsep, Teori, dan Terapan . Yogyakarta: Morfalingua.

Faruk. 1994. Pengantar Sosiologi Sastra. Yogyakarta: Pustaka Pelajar.

Febrianti, Binar Kurniasari. 2019. "Seminar Hasil Penelitian Kebahasaan dan Kesastraan." Prosiding, Lingkungan Alam dalam Singkawang Antologi Sajak Pradono, Balai Bahasa Kalimantan Barat, Pontianak.

Fuad, Khairul. 2016. Mukasyafah Cinta Pontianak dari Menyingkap Sastra Sampai Menyibak Budaya Cuplikan di Borneo Tribune. Pontianak: STAIN Pontianak Press. .2017. "Keseimbangan Lingkungan dalam Puisi Teratak Lima." Prosiding, Seminar Nasional Bahasa, Sastra, dan Seni Pentingnya Peran Bahasa, Sastra, dan Seni dalam Pelestarian Budaya Lokal, Fakultas Ilmu Budaya Universitas Mulawarman, Samarinda.

Mahayana, Maman S. 2005a. 9 Jawaban Sastra Indonesia Sebuah Orientasi Kritik. Jakarta: Bening Publishing. 2005b. 9 Jawaban Sastra Indonesia Sebuah Orientasi Kritik. Jakarta: Bening Publishing.

Pradono, ed. 2012. Cahaya Khatulistiwa di Taman Kata. Pontianak: Dewan Kesenian Kota Pontianak.

Pradono. 2017. Singkawang Antologi Sajak Pradono. Pontianak: Pustaka Rumah Aloy.

Saragih, Sahat Oloan. 2018. "Sungai Kapuas Tercemar Merkuri." Diunduh 7 Mei 2020, (www.beritasatu.com).

Setia, Ilham. 2014. Kama Kumpulan Puisi. Pontianak: Pijar Publishing.

Sudjiman, Panuti dan Aart van Zoest, eds. 1996. Serba-Serbi Semiotika. Jakarta: Gramedia Pustaka Utama.

Suwondo, Tirto. 2011. Membaca Sastra Membaca Kehidupan. Yogyakarta: Hikayat Publishing.

Umar, Fadiah, Siti Nurisjah, dan Ricky Avenzora. 2010. "Identifikasi dan Rencana Pengembangan Kawasan Wisata Budaya Koridor Sungai Kapuas-Kota Pontianak."Jurnal Lanskap Indonesia 2(1):1-6.

Yusriadi dan Hermansyah. 2003. Orang Embau Potret Masyarakat Pedalaman Kalimantan Barat. Pontianak: STAIN Pontianak Press kerjasama Yayasan Adikarya IKAPI dan The Ford Foundation. 